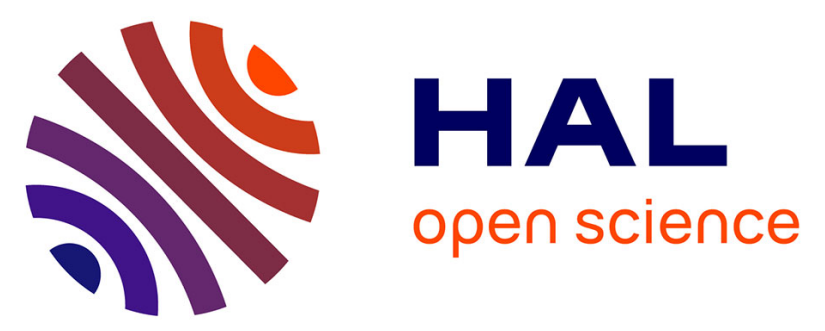

\title{
Analysis of adulterated herbal medicines and dietary supplements marketed for weight loss by DOSY $1 \mathrm{H}$ NMR
}

Julie Vaysse, Stéphane Balayssac, Véronique Gilard, Denis Desoubzdanne, Myriam Malet-Martino, Robert Martino

\section{To cite this version:}

Julie Vaysse, Stéphane Balayssac, Véronique Gilard, Denis Desoubzdanne, Myriam MaletMartino, et al.. Analysis of adulterated herbal medicines and dietary supplements marketed for weight loss by DOSY 1H NMR. Food Additives and Contaminants, 2010, 27 (07), pp.903-916. 10.1080/19440041003705821 . hal-00598944

\section{HAL Id: hal-00598944 \\ https://hal.science/hal-00598944}

Submitted on 8 Jun 2011

HAL is a multi-disciplinary open access archive for the deposit and dissemination of scientific research documents, whether they are published or not. The documents may come from teaching and research institutions in France or abroad, or from public or private research centers.
L'archive ouverte pluridisciplinaire HAL, est destinée au dépôt et à la diffusion de documents scientifiques de niveau recherche, publiés ou non, émanant des établissements d'enseignement et de recherche français ou étrangers, des laboratoires publics ou privés. 


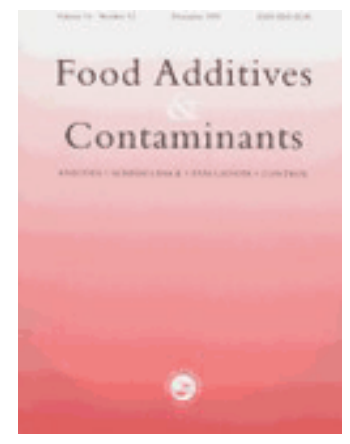

\section{Analysis of adulterated herbal medicines and dietary supplements marketed for weight loss by DOSY $1 \mathrm{H}$ NMR}

\begin{tabular}{|r|l|}
\hline Journal: & Food Additives and Contaminants \\
\hline Manuscript ID: & TFAC-2009-378.R1 \\
\hline Manuscript Type: & Original Research Paper \\
\hline Author: & 14-Feb-2010 \\
\hline Complete List of Authors: & $\begin{array}{l}\text { VAYSSE, Julie; Université Paul Sabatier, SPCMIB Lab } \\
\text { BALAYSSAC, Stéphane; Université Paul Sabatier, SPCMIB Lab } \\
\text { GILARD, Véronique; Université Paul Sabatier, SPCMIB Lab } \\
\text { DESOUBZDANNE, Denis; Université Paul Sabatier, SPCMIB Lab } \\
\text { MALET-MARTINO, Myriam; Université Paul Sabatier, SPCMIB } \\
\text { MARTINO, Robert; Université Paul Sabatier, SPCMIB Lab }\end{array}$ \\
\hline Methods/Techniques: & Analysis - NMR \\
\hline Additives/Contaminants: & Additives general \\
\hline Food Types: & Nutritional supplements \\
\hline & \\
\hline
\end{tabular}

\section{SCHOLARONE Manuscripts}




\title{
Analysis of adulterated herbal medicines and dietary supplements marketed for weight loss by DOSY ${ }^{1} \mathrm{H}$ NMR
}

\author{
Julie VAYSSE, Stéphane BALAYSSAC, Véronique GILARD, \\ Denis DESOUBDZANNE, Myriam MALET-MARTINO*, Robert MARTINO \\ Université de Toulouse; UPS; Laboratoire de Synthèse et Physico-Chimie de Molécules \\ d'Intérêt Biologique (SPCMIB), Groupe de RMN Biomédicale; 118 route de Narbonne, \\ 31062 Toulouse cedex 9, France
}

\author{
Myriam Malet-Martino*: tel 335615568 90; fax 33561557625 \\ martino@chimie.ups-tlse.fr
}

\begin{abstract}
Keywords: slimming products; herbal medicines; dietary supplements; adulteration; synthetic drugs; ${ }^{1} \mathrm{H}$ NMR; 2D and 3D DOSY ${ }^{1} \mathrm{H}$ NMR; sibutramine; phenolphthalein; synephrine
\end{abstract}




\begin{abstract}
Twenty herbal medicines or dietary supplements marketed as natural slimming products were analyzed by Diffusion Ordered SpectroscopY (DOSY) ${ }^{1} \mathrm{H}$ NMR and DOSY-COSY ${ }^{1} \mathrm{H}$ NMR. The method allows analysis of the whole sample with detection of both active and inactive ingredients in these complex matrices. Among the 20 formulations analyzed, 2 were strictly herbal and 4 had a composition corresponding to declared ingredients on the packaging or the leaflet. The others were all adulterated. Eight formulations contain sibutramine alone at doses ranging from 4.4 to $30.5 \mathrm{mg} /$ capsule. Five formulations contain sibutramine (from 5.0 to 19.6 $\mathrm{mg} / \mathrm{capsule}$ or tablet) in combination with phenolphthalein (from 4.4 to $66.1 \mathrm{mg} / \mathrm{capsule}$ ), and the last formulation was adulterated with synephrine (19.5 mg/capsule). Quantification of the actives was carried out with ${ }^{1} \mathrm{H}$ NMR. Several other compounds were also characterized including methylsynephrine, vitaberin, sugars, vitamins etc. DOSY NMR is thus proposed as a useful tool for detection of unexpected adulteration.
\end{abstract}




\section{Introduction}

According to WHO (http://www.who.int/mediacentre/factsheets/fs311/en/), approximately 1.6 billion adults were overweight and at least 400 million were obese in 2005 . WHO further projects that by 2015 , approximately 2.3 billion adults will be overweight and more than 700 million will be obese. Overweight and obesity are associated with premature mortality, chronic morbidity, diabetes, heart disease, osteoarthritis and cancer. Given (i) the medical and social impact of being overweight or obese, (ii) the few drugs marketed for these indications, and (iii) the safety concerns of these medications, more and more patients turn to weight-loss natural herbal medicines (HM) or dietary supplements (DS). Indeed, in contrast to conventional pharmaceuticals, these products are regarded by many as being harmless because of their natural origin for HM or of their safe composition (vitamins, minerals, herbs or other botanicals, amino acids, and substances such as enzymes, organ tissues, glandular, and metabolites) for DS.

The WHO's definition indicates that medicines containing plant material combined with chemically defined active substances, including chemically defined, isolated constituents of plants, are not considered to be HM (http://www.who.int/medicines/areas/traditional/ definitions/en/index.html). Moreover, FDA regulations require that a complete list of ingredients and the net contents of the product appear on DS labels (http://www.fda.gov/ food/DietarySupplements/default.htm). Despite these clear definition and regulation and as it is very easy for the consumer to purchase these formulations over the Internet, common problems affecting the safety of these preparations include fraudulent adulteration with synthetic actives used in conventional pharmaceutical drugs which can lead to severe sideeffects.

Reported methods for screening illegal adulterations in HM or DS are mainly HPLCDAD, GC-MS and LC/MS/MS (Liu et al. 2001; Lau et al. 2003; Bogusz et al. 2006; Liang et 
al. 2006; Chen et al. 2009). Recently, Zhu et al. (2009) developed an algorithm, termed local straight-line screening (LSLS), to resolve complex IR spectra of possibly adulterated HM. The analytical methods reported concerning more specifically the adulteration of herbal formulations marketed for weight loss are chromatographic methods coupled with various detectors (Tseng et al. 2000; Jung et al. 2006; Yuen et al. 2007; Zou et al. 2007; Date et al. 2008; Huang et al. 2008; Wang et al. 2008), capillary electrophoresis (CE) (Cianchino et al. 2008) and IR-LSLS (Lu et al. 2007). None of these methods is ideal as HM often contain mixture of herbs and other natural products, and the formulas of those products are very complex. Chromatographic methods do not provide global information as they are mainly targeted screening methods and thus sometimes too selective. Moreover, false-positive results might occur with both chromatographic and IR-LSLS methods because it is in fact an analogue of a known active compound with a very close chemical structure which is detected instead of the target compound.

In this study we show an application of 2D Diffusion Ordered SpectroscopY ${ }^{1} \mathrm{H}$ Nuclear Magnetic Resonance (2D DOSY ${ }^{1} \mathrm{H}$ NMR) spectroscopy as an untargeted screening method for the detection and unequivocal identification of adulterants in "herbal" slimming products. The main advantage of NMR is to provide global information as it allows for considering the drug preparation as a whole. Moreover, the method is non-selective and requires no prior knowledge of the structures of the various components present in the mixture, which is a major advantage for screening of adulteration.

\section{Experimental}

\section{Samples}

Twenty commercial formulations of HM or DS marketed for weight loss were analyzed. Formulations 1, 5, and 7 were bought in China and formulations $\mathbf{1 6 - 1 8}$ in Syria. Other formulations were purchased over the internet. The list of the tablets or capsules analyzed is 
given in Table 1. All samples, as received, were stored in the dark at ambient temperature and humidity. They were all analyzed within their expiration dates (when indicated).

\section{${ }^{1} \mathrm{H}$ and $2 \mathrm{D}$ DOSY ${ }^{1} \mathrm{H} N M R$}

The ${ }^{1} \mathrm{H}$ NMR experiments were performed on a Bruker Avance 500 spectrometer equipped with a $5 \mathrm{~mm}$ cryoprobe at $298 \mathrm{~K}$. Typical acquisition parameters were as follows: acquisition time $2.72 \mathrm{~s}$, spectral width $6000 \mathrm{~Hz}$, pulse width $3.0 \mu$ s (flip angle $\approx 35^{\circ}$ ), $32 \mathrm{~K}$ data points, relaxation delay $1 \mathrm{~s}$ and number of scans 16 . All chemical shifts $(\delta)$ were referred to an internal $\delta$ and quantification sodium 2,2,3,3-tetradeutero-3-trimethylsilylpropionate (TSP) reference. Authentic standards (sibutramine, phenolphthalein, synephrine, vitaberine, caffeine, carnitine, linoleate, stearate, citrate, vitamin C, dehydroascorbic acid, vitamins B1, B2, B3, B5, B6, and E, lipoic acid, glucose, fructose and sucrose) were added into the samples to assign resonances in the ${ }^{1} \mathrm{H}$ NMR spectra. Moreover, 1D ${ }^{1} \mathrm{H}$ NMR spectra extracted from the 2D DOSY ${ }^{1} \mathrm{H}$ NMR spectrum also helped to substantiate compound identification.

Relaxation delay was lengthened to $3 \mathrm{~s}$ and 128 scans were recorded for the quantitative analysis of sibutramine, phenolphthalein, synephrine, methylsynephrine, caffeine and vitaberine. The concentrations of adulterant compounds were measured by comparing the expanded areas of their respective NMR signals with that of the internal standard for quantification TSP. The areas were determined by manual integration using TopSpin software. Each data is the mean of at least five integrations. In order to check that the NMR conditions used allowed an accurate quantitation of adulterants, a longer interval between pulses (10 s) was used in some experiments. The same concentration values were obtained, thus demonstrating that a pulse interval of $3 \mathrm{~s}$ for a flip angle of $35^{\circ}$ is sufficient to record the spectra under conditions of full $T_{1}$ relaxation. Sibutramine was assayed from the singlet at $7.47 \mathrm{ppm}$, phenolphthalein from the two doublets at 7.17 and $6.84 \mathrm{ppm}$, synephrine from the 
two doublets at 7.23 and $6.83 \mathrm{ppm}$, methylsynephrine from the two doublets at 7.20 and 6.83 ppm, caffeine from the singlet at $7.77 \mathrm{ppm}$ in formulation $\mathbf{1 2}$ and from the two singlets at 3.93 and $3.50 \mathrm{ppm}$ in formulation 19, and vitaberine from the triplet at $4.04 \mathrm{ppm}$. The limit of quantification of the NMR assay in the recording conditions used in this study is $5 \mu \mathrm{M}$.

Stimulated echo bipolar gradient pulse experiments were used for 2D DOSY ${ }^{1} \mathrm{H}$ NMR with a pulse field gradient length between 1.4 and $1.8 \mathrm{~ms}$, a delay of $3 \mathrm{~ms}$ after each gradient and a diffusion delay between 50 and $100 \mathrm{~ms}$. Sequence parameters were optimized in order to have the intensity of the main signals of the spectrum in the aromatic region strongly decreased (at least divided by 50 ) at $95 \%$ of the full gradient strength. The longitudinal eddy current delay was $20 \mathrm{~ms}$, spoiler gradients were $1 \mathrm{~ms}$ long with a field strength of -7.92 and $6.09 \mathrm{G} . \mathrm{cm}^{-1}$ and other acquisition parameters were the same as those reported above for 1D ${ }^{1} \mathrm{H}$ NMR except for the relaxation delay fixed to 2 s. Forty experiments were recorded with gradient intensity linearly sampled from 5 to $95 \%$. The gradient system had been calibrated to 46.25 G.cm ${ }^{-1}$ at maximum intensity.

All data were processed using the Gifa 5.2 software with the inverse Laplace transform method using the Maximum Entropy (MaxEnt) algorithm. The processing parameters were 2048 points along the Laplace spectrum diffusion axis and 20000 MaxEnt iterations. The inverse Laplace transform was computed only on the columns presenting a signal 32 times greater than the noise level of the experiment. DOSY spectra are presented with chemical shifts on the horizontal axis and diffusion coefficients expressed in $\mu \mathrm{m}^{2} . \mathrm{s}^{-1}$ on the vertical axis.

The 3D DQF-COSY iDOSY experiment was recorded on formulation 7. In the diffusion dimension, 28 gradient steps were used with $50 \mathrm{~ms}$ for the diffusion delay, $1.9 \mathrm{~ms}$ for the gradient pulse length and $3 \mathrm{~ms}$ for the recovery delay. In the COSY dimension, $8192 \times 104$ data points were used, corresponding to $0.74 \mathrm{~s}$ for acquisition time and $8.6 \mathrm{~ms}$ for the other 


\section{MS-MS analysis}

An Applied System QTRAP triple-quadrupole mass spectrometer, equipped with a Turbo Ion Spray (TIS) interface and controlled by the Agilent Analyst software (version 1.4), was used for analysis. The mass spectrometer was operated in positive ionization mode. Nitrogen served both as auxiliary, collision gas and nebulizer gas. The operating conditions for TIS interface were as follows: (i) in MS mode: mass range 100-600 u (1 s), step size 0.1 u; Q1 TIS MS spectra were recorded in profile mode, IS $5000 \mathrm{~V}$, DP $40 \mathrm{~V}$; (ii) in MS-MS mode: precursor mass $280 \mathrm{u}$; mass range 30-300 u; step size $0.1 \mathrm{u}$; MS-MS spectra were recorded in profile mode, IS $5000 \mathrm{~V}$, DP $40 \mathrm{~V}$, CE $20 \mathrm{~V}$. All samples were dissolved in $\mathrm{MeOH}$ and analyzed after direct introduction.

\section{Preparation of samples for NMR analysis}

The tablets were powdered (or capsule emptied) and dissolved in $5 \mathrm{~mL}$ of $\mathrm{CD}_{3} \mathrm{CN}: \mathrm{D}_{2} \mathrm{O}$ $80: 20 \mathrm{v} / \mathrm{v}\left(\mathrm{CD}_{3} \mathrm{CN}\right.$ for formulation 8 and $\mathrm{D}_{2} \mathrm{O}$ for formulation 16) under magnetic stirring 
during $10 \mathrm{~min}$ and then sonicated for $10 \mathrm{~min}$. The suspension was then centrifuged $(5 \mathrm{~min}$, $3000 \mathrm{rpm})$ and the supernatant $(550 \mu \mathrm{L})$ analyzed.

For the quantitative analysis of sibutramine, phenolphthalein, synephrine, methylsynephrine, vitaberine and caffeine found in some formulations, the tablet was powdered (or capsule emptied), and $10 \%$ of the powder was dissolved in $10 \mathrm{~mL}$ of methanol under magnetic stirring during $15 \mathrm{~min}$ and then sonicated for $10 \mathrm{~min}$. An aliquot of $1 \mathrm{~mL}$ was evaporated to dryness and the residue dissolved in $1 \mathrm{~mL}$ of $\mathrm{MeOH}-\mathrm{d}_{4}$. TSP was added at a final concentration of $0.2 \mathrm{mM}$ before the NMR analysis. The experiments were done in triplicate.

\section{Results}

\section{Conventional ${ }^{1} H$ NMR and $2 D$ DOSY ${ }^{1} H$ NMR analyses}

All formulations were analyzed with 2D DOSY ${ }^{1} \mathrm{H}$ NMR. 2D DOSY spectra of formulations 3, 12 and 19 along with their corresponding 1D spectrum are presented in Figure 1. All the peaks of a same compound are lined up. The peaks at 3.62 and $1.99 \mathrm{ppm}$ correspond to the signals of residual $\mathrm{HOD}$ in $\mathrm{D}_{2} \mathrm{O}$ and $\mathrm{CHD}_{2} \mathrm{CN}$ in acetonitrile- $\mathrm{d}_{3}$, respectively. As shown in Figure 1, the separation according to diffusion coefficients (D) in the diffusion dimension allows an easier identification of the components of a mixture. Indeed, in formulation 3 (Figure 1A), the active pharmaceutical ingredient (API) adulterant is sibutramine ( $\mathrm{D}=1107 \pm$ $\left.9 \mu \mathrm{m}^{2} \cdot \mathrm{s}^{-1}\right)$ citrate $\left(\mathrm{D}=959 \mu \mathrm{m}^{2} \cdot \mathrm{s}^{-1}\right)$ and low amounts of natural compounds including glucose, sucrose, and fatty acids $(\mathrm{D}=931 \pm 29,1006 \pm 29$, and $872 \pm 29$, respectively $)$ are also detected. In formulation 12 (Figure 1B), the main signals are those of caffeine $(\mathrm{D}=1156 \pm$ $\left.39 \mu \mathrm{m}^{2} \cdot \mathrm{s}^{-1}\right)$ and synephrine $\left(\mathrm{D}=734 \pm 20 \mu \mathrm{m}^{2} \cdot \mathrm{s}^{-1}\right)$, whereas formulation 19 (Figure 1C) contains caffeine, methylsynephrine, vitaberine (thiamine-O-isobutyryl disulphide) and 
stearate with diffusion coefficients of $1288 \pm 93,851 \pm 41,624 \pm 9$ and $918 \mu \mathrm{m}^{2} . \mathrm{s}^{-1}$, respectively.

All the ingredients detected in the herbal drugs studied are reported in Table 2, which shows the comparison between the indications provided by the manufacturer and the compounds found in each formulation. Several unexpected actives, sibutramine (formulations 1-5, 7-11, 13-15), phenolphthalein (formulations 1, 5, 7, 9, 15) synephrine and caffeine (formulation 12), were found. The unambiguous identification of the components in the herbal formulations analyzed was achieved by comparison of $1 \mathrm{D}{ }^{1} \mathrm{H}$ NMR data of standards, addition of authentic standards, and comparison of 1D NMR spectra extracted from the 2D DOSY ${ }^{1} \mathrm{H}$ NMR spectrum with those of authentic standards (Figure 1D).

The NMR spectral data of sibutramine measured in $\mathrm{CD}_{3} \mathrm{CN}: \mathrm{D}_{2} \mathrm{O}(80: 20)$ are reported in Table 3. The ${ }^{1} \mathrm{H}$ NMR resonances were assigned by 2D NMR (gCOSY, gHSQC, gHMBC, gNOESY) and 1D selective NOE experiments. The chemical shifts and coupling constants of all the other ingredients are reported in Table 4.

Even if sensitivity is not an issue with respect to adulteration, we determined that in the experimental conditions used in this study (1h of recording), 2D DOSY ${ }^{1} \mathrm{H}$ NMR allows an accurate determination of diffusion coefficients for compounds at a concentration of $50 \mu \mathrm{M}$. The limit of detection corresponds to $10 \mu \mathrm{M}$ with only $\mathrm{CH}_{2}$ and $\mathrm{CH}_{3}$ signals being detected.

\section{D DOSY-COSY ${ }^{1} \mathrm{H}$ NMR analysis}

Figure 2 illustrates the different NMR spectra obtained in the 3D DOSY-COSY ${ }^{1} \mathrm{H}$ NMR experiment applied to formulation 7. First, the classical 2D DOSY (Figure 2A) and COSY-DQF (Figure 2B) spectra are shown. In the COSY spectrum, diagonal signals and offdiagonal cross peaks of sibutramine, phenolphthalein, glucose and sucrose are observed. Other spectra (2C and 2D) are those of the projections from the 3D DOSY-COSY experiment. The main interest of this 3D experiment is to extract the COSY spectrum of each 
component of the mixture from a selected line in the DOSY spectrum. For example, Figure 2C shows the COSY projection of phenolphthalein at $\mathrm{D}=990 \mu \mathrm{m}^{2} . \mathrm{s}^{-1}$; typical cross peaks of aromatic signals are detected for this compound while the on-diagonal signal from aromatic protons of sibutramine has disappeared. The COSY projection corresponding to $\mathrm{D}=711$ $\mu \mathrm{m}^{2} \cdot \mathrm{s}^{-1}$ (Figure 2D) shows exclusively the signals of sucrose without any signal from phenolphthalein or anomeric protons from $\alpha$ - or $\beta$-glucose. These spectra highlight the interest of 3D experiment as virtual separation provided by DOSY acquisition can lead to structural determination by extraction of COSY spectra.

\section{Quantitative analysis}

The contents of sibutramine and phenolphthalein in the herbal drugs analyzed were measured by NMR (Table 5). Eight formulations (2, 3, 4, 8, 10, 11, 13, 14) contain sibutramine alone at doses ranging from 4.4 to $30.5 \mathrm{mg} /$ capsule. Five formulations $(\mathbf{1 , ~ 5 , ~ 7 , ~ 9 , ~}$ 15) contain sibutramine (from 5.0 to $19.6 \mathrm{mg} / \mathrm{capsule}$ or tablet) and phenolphthalein (from 4.4 to $66.1 \mathrm{mg} / \mathrm{capsule})$. Formulation 12 contains $19.5 \pm 0.5$ and $10.0 \pm 0.5 \mathrm{mg} / \mathrm{capsule}$ of synephrine and caffeine, respectively. Formulation 19 contains $38.3 \pm 0.9,184.9 \pm 5.6$ and $75.4 \pm 1.6 \mathrm{mg} /$ capsule of methylsynephrine, caffeine and vitaberine, respectively.

\section{Mass spectrometry}

The aim of mass spectrometry experiments was to cross-validate NMR data. MS/MS mass spectrometry with ESI ionization was carried out in order to confirm the presence of sibutramine and to investigate the presence of its previously described mono- or didesmethylated analogs (Wang et al. 2008). Molecular $[\mathrm{M}+\mathrm{H}]^{+}$ions corresponding to sibutramine, N-mono-desmethylsibutramine and N-di-desmethylsibutramine were searched at $\mathrm{m} / \mathrm{z}$ 280, 266 and 252, respectively (Wang et al. 2008). Only sibutramine was found. MS/MS was then carried out on the m/z 280 ion giving characteristic fragments at m/z 153, 139, and 


\section{Discussion}

To date, identification of synthetic drugs adulterating HM to inhibit appetite and achieve weight loss using NMR and more specifically $2 \mathrm{D}$ DOSY ${ }^{1} \mathrm{H}$ NMR has not been reported. The objective of this study was to apply this method to analyze the content of 20 different HM or DS.

Chromatographic methods are preferred by most analysts for mixture analysis as they are very common, easy to handle, quantitative, sensitive, relatively cheap and do not require highly trained personnel. Nevertheless, NMR has also several advantages; it is non-selective, quantitative, highly powerful for structural elucidation and it requires no prior knowledge of the structures of the various components present in a mixture. 2D DOSY ${ }^{1} \mathrm{H}$ NMR allows the virtual separation of several components of a mixture in a single run based on the difference in their translational self-diffusion coefficients (Figure 1). Moreover, DOSY experiments do not need complicated setup procedures or separation steps and the method can be used routinely. This technique has been used successfully for analyzing several kinds of counterfeit drugs (Trefi et al. 2008; Nyadong et al. 2009). Table 6 shows a comparison on information obtained with various analytical methods on slimming herbal drug composition and highlights the interest of DOSY NMR for a global analysis of these formulations.

Among the 20 formulations analyzed, 2 were strictly herbal (formulations $\mathbf{1 7}$ and 18), and 4 had a composition corresponding to declared ingredients on the packaging or the leaflet (formulations 6, 16, 19, 20). The others were all adulterated. Thirteen formulations (1-5, 7-11, 
13-15) contained sibutramine alone or in combination with phenolphthalein $(\mathbf{1}, \mathbf{5}, \mathbf{7}, \mathbf{9}$, and 15). The two metabolites of sibutramine, N-mono- and N-di-desmethylsibutramine, previously described by some authors (Blachut et al. 2007; Lai et al. 2007; Yuen et al. 2007; Huang et al. 2008) as possible adulterants in slimming dietary supplements were not detected in our samples neither with NMR nor with MS and MS/MS analyses. The amount of sibutramine found in adulterated formulations ranged from 4.4 (formulation 2) to 30.5 $\mathrm{mg} /$ capsule (formulation 11). The recommended daily dose is 5 to $15 \mathrm{mg}, 15 \mathrm{mg}$ being the maximum daily dose (de Simone and D'Addeo 2008). Three formulations (3, 5 and 11) were thus overdosed, which poses a serious health risk to consumers and particularly a cardiovascular risk as an increase in systolic blood pressure has been noticed in patients receiving sibutramine at the non recommended doses of 20 or $30 \mathrm{mg}$ (Narkiewicz 2002). Several cases of mild to severe poisoning due to herbal slimming medicines adulterated with sibutramine (Lida (Jung et al. 2006; Müller et al. 2009), Ever Youth and unknown (Yuen et al. 2007), Meizitanc (Sein Anand and Chodorowski, 2007)) have been recently reported. It is interesting to point out that during the reviewing process of this article, the European Medicines Agency's Committee for Medicinal Products for Human Use has concluded that the benefits of sibutramine do not outweigh its risks, and that all marketing authorizations for medicines containing sibutramine should be suspended throughout Europe (http://www.ema.europa.eu/pdfs/human/referral/sibutramine/3940810en.pdf).

Other actives found may also cause serious adverse effects. Phenolphthalein is a laxative that was withdrawn as a medicine several years ago after concerns about carcinogenicity (No authors listed 1999). Moreover, interaction profiles are unknown for the combination sibutramine/phenolphthalein. After the ban on ephedrines in 2004, manufacturers changed to using the weaker stimulant synephrine that has purported thermogenic and lipolytic properties due to its $\alpha$-adrenergic agonist property (Haaz et al. 2006). The safety of synephrine is 
controversial but it could pose cardiovascular health risks (Haaz et al. 2006), especially in combination with caffeine (Haller et al. 2005). Formulation 12, claimed as purely herbal, contains both compounds and formulation 19 contains methylsynephrine (parahydroxyephedrine) in combination with a high dose of caffeine, a potentially hazardous combination.

\section{Conclusion}

This study presents a new application of 2D DOSY ${ }^{1} \mathrm{H}$ NMR for the analysis of HM and DS, which are undeniable complex mixtures. Among the twenty formulations marketed for weight loss studied thirteen were adulterated with sibutramine alone or with a combination of sibutramine and phenolphthalein. Adulteration of "natural herbal medicines" with undeclared synthetic drugs is a common and dangerous phenomenon and all the analytical methods that ensure the quality and safety of these products have thus to be developed. In this context, 2D DOSY ${ }^{1} \mathrm{H}$ NMR spectroscopy is a powerful method for providing a multivariate fingerprint of a very complex mixture especially in situations where the identity of the components is not known beforehand as it permits to consider the drug preparation as a whole. The technique should be now considered as a useful and complementary tool among a standard 2D NMR analytical package. Moreover, its evolution towards 3D DOSY-COSY experiments noticeably increases its interest as structural data are easily obtained.

\section{Acknowledgements}

The authors wish to thank Marie-José Parent and Dr Saleh Trefi for helpful discussion on herbal drug adulteration and Catherine Claparols for mass spectrometry experiments. 


\section{References}

Blachut D, Siwinska-Ziolkowska A, Szukalski B, Wojtasiewicz K, Czarnocki Z, Kobylecka A, Bykas-Strekowska M. 2007. Identification of N-desmethylsibutramine as a new ingredient in Chinese herbal dietary supplements. Probl Forensic Sci. 70:225-235.

Bogusz MJ, Hassan H, Al-Enazi E, Ibrahim Z, Al-Tufail M. 2006 Application of LC-ESIMS-MS for detection of synthetic adulterants in herbal remedies. J Pharm Biomed Anal. 41:554-564.

Chen Y, Zhao L, Lu F, Yu Y, Chai Y, Wu Y. 2009. Determination of synthetic drugs used to adulterate botanical dietary supplements using QTRAP LC-MS/MS. Food Add Cont. 26:595603.

Cianchino V, Acosta G, Ortega C, Martinez LD, Gomez MR. 2008. Analysis of potential adulteration in herbal medicines and dietary supplements for the weight control by capillary electrophoresis. Food Chem. 108:1075-1081.

Date H, Toyota A, Terauchi M, Sugimura M, Matsuo T, Mochiike C. 2008. Rapid determination of medical components found in the health food for weight loss by liquid chromatography/tandem mass spectrometry (LC/MS/MS). Yakugaku Zasshi. 128:811-817.

de Simone G, D'Addeo G. 2008. Sibutramine: balancing weight loss benefit and possible cardiovascular risk. Nutr Metab Cardiovasc Dis. 18:337-341.

Haaz S, Fontaine KR, Cutter G, Limdi N, Perumean-Chaney S, Allison DB. 2006. Citrus aurantium and synephrine alkaloids in the treatment of overweight and obesity: an update. Obes Rev. 7:79-88.

Haller CA, Benowitz NL, Jacob P. 2005. Hemodynamic effects of ephedra-free weight-loss supplements in humans. Am J Med. 118:998-1003.

Huang Z, Xiao S, Luo D, Chen B, Yao S. 2008. Simultaneous determination of sibutramine and N-di-desmethylsibutramine in dietary supplements for weight control by HPLC-ESI-MS. J Chromatogr Sci. 46:707-711.

Jung J, Hermanns-Clausen M, Weinmann W. 2006. Anorectic sibutramine detected in a Chinese herbal drug for weight loss. Forensic Sci Int. 161:221-222.

Lai KC, Liu YC, Tseng MC, Lin YL, Lin JH 2007 Isolation and identification of a sibutramine analogue in a healthy food for weight loss. J Food Drug Anal. 15:20-24.

Lau AJ, Holmes MJ, Woo SO, Koh HL. 2003. Analysis of adulterants in a traditional herbal medicinal product using liquid chromatography-mass spectrometry-mass spectrometry. $\mathrm{J}$ Pharm Biomed Anal. 31:401-406.

Liang Q, Qu J, Luo G, Wang Y. 2006. Rapid and reliable determination of illegal adulterant in herbal medicines and dietary supplements by LC/MS/MS. J Pharm Biomed Anal. 40:305311.

Liu SY, Woo SO, Koh HL. 2001. HPLC and GC-MS screening of Chinese proprietary medicine for undeclared therapeutic substances. J Pharm Biomed Anal. 24:983-992. 
Lu F, Li S, Le J, Chen G, Cao Y, Qi Y, Chai Y, Wu Y. 2007. A new method for testing synthetic drugs adulterated in herbal medicines based on infrared spectroscopy. Anal Chim Acta. 589:200-207.

Müller D, Weinmann W, Hermanns-Clausen M. 2009. Chinese slimming capsules containing sibutramine sold over the Internet: a case series. Dtsch Arztebl Int. 106:218-222.

Narkiewicz K. 2002. Sibutramine and its cardiovascular profile. Int J Obes. 26:S38-S41.

Nyadong L, Harris GA, Balayssac S, Galhena AS, Malet-Martino M, Martino R, Parry RM, Wang MD, Fernandez FM, Gilard V. 2009. Combining two-dimensional diffusion-ordered nuclear magnetic resonance spectroscopy, imaging desorption electrospray ionization mass spectrometry and direct analysis in real time mass spectrometry for the integral investigation of counterfeit pharmaceuticals. Anal Chem. 81:4803-4812.

NMRtec, Nmrnotebook software. Available from: <http://www.NMRnotebook.com>

No authors. 1999. Laxative drug products for over-the-counter human use. Food and Drug Administration, HHS. Final rule. Fed Regist. 64:4535-4540.

Sein Anand J, Chodorowski Z. 2007. Side effects after the usage of Chinese dieting product Meizitanc. Przegl Lek. 64:346-347.

Tramesel D, Catherinot V, Delsuc MA. 2007. Modeling of NMR processing, toward efficient unattended processing of NMR experiments. J Magn Reson 188:56-67.

Trefi S, Routaboul C, Hamieh S, Gilard V, Malet-Martino M, Martino R. 2008. Analysis of illegally manufactured formulations of tadalafil (Cialis®) by ${ }^{1} \mathrm{H}$ NMR, 2D DOSY ${ }^{1} \mathrm{H}$ NMR and Raman spectroscopy. J Pharm Biomed Anal. 47:103-113.

Tseng MC, Tsai MJ, Lin JH, Wen KC. 2000. GC/MS analysis on anorectics adulterated in traditional Chinese medicines. J Food Drug Anal. 8:315-330.

Wang J, Chen B, Yao S. 2008. Analysis of six synthetic adulterants in herbal weight-reducing dietary supplements by LC electrospray ionization-MS. Food Addit Contam. 25:822-830.

Yuen YP, Lai CK, Poon WT, Ng SW, Chan AYW, Mak TWL. 2007. Adulteration of overthe-counter slimming products with pharmaceutical analogue-an emerging threat. Hong Kong Med J. 13:216-220.

Zhu X, Zhang Z, Lu F, Wu Y, Qi Y. 2009. Modified local straight-line screening to detect synthetic drugs in adulterated herbal medicines. Appl Spectrosc. 63:471-476

Zou P, Oh SS-Y, Kiang K-H, Low M-Y, Bloodworth BC. 2007. Detection of sibutramine, its two metabolites and one analogue in a herbal product for weight loss by liquid chromatography triple quadrupole mass spectrometry and time-of-flight mass spectrometry. Rapid Commun Mass Spectrom. 21:614-618. 


\section{Captions for figures}

Figure 1. 2D DOSY ${ }^{1} \mathrm{H}$ NMR spectra recorded in $\mathrm{CD}_{3} \mathrm{CN}: \mathrm{D}_{2} \mathrm{O}(80 / 20)$ of formulations 3 (A), 12 (B) and 19 (C). (D) Comparison of 1D ${ }^{1} \mathrm{H}$ NMR spectra of caffeine (D1) and vitaberine (D2) extracted from the 2D DOSY ${ }^{1}$ H NMR spectrum of formulation 19 with those of authentic standards.

sib, sibutramine; caf, caffeine; syn, synephrine; msyn, methylsynephrine; vita: vitaberine; fa, fatty acids; st, stearate; TSP, sodium 2,2,3,3-tetradeutero-3-trimethylsilylpropionate (internal standard); ?, unknown; sib* means that the diffusion coefficient of this sibutramine signal is lower due to its superimposition with $\mathrm{CHD}_{2} \mathrm{CN}$, which affects DOSY processing. A deeper section of some signals is shown in box with dotted lines.

Figure 2. NMR spectra of formulation 7 in $\mathrm{CD}_{3} \mathrm{CN}: \mathrm{D}_{2} \mathrm{O}(80 / 20)$. (A) $2 \mathrm{D}$ DOSY ${ }^{1} \mathrm{H}$ spectrum; (B) COSY-DQF spectrum; COSY extractions from 3D DOSY-COSY experiment at $(C) D=990 \mu \mathrm{m}^{2} \cdot \mathrm{s}^{-1},(\mathrm{D}) \mathrm{D}=711 \mu \mathrm{m}^{2} \cdot \mathrm{s}^{-1}$.

sib, sibutramine; phth, phenolphthalein; sucr, sucrose; gluc, glucose; st, stearate; S, satellite signals from $\mathrm{CHD}_{2} \mathrm{CN}$; TSP, sodium 2,2,3,3-tetradeutero-3-trimethylsilylpropionate (internal standard); sib* means that the diffusion coefficient of this sibutramine signal is lower due to its superimposition with $\mathrm{CHD}_{2} \mathrm{CN}$, which affects DOSY processing. 


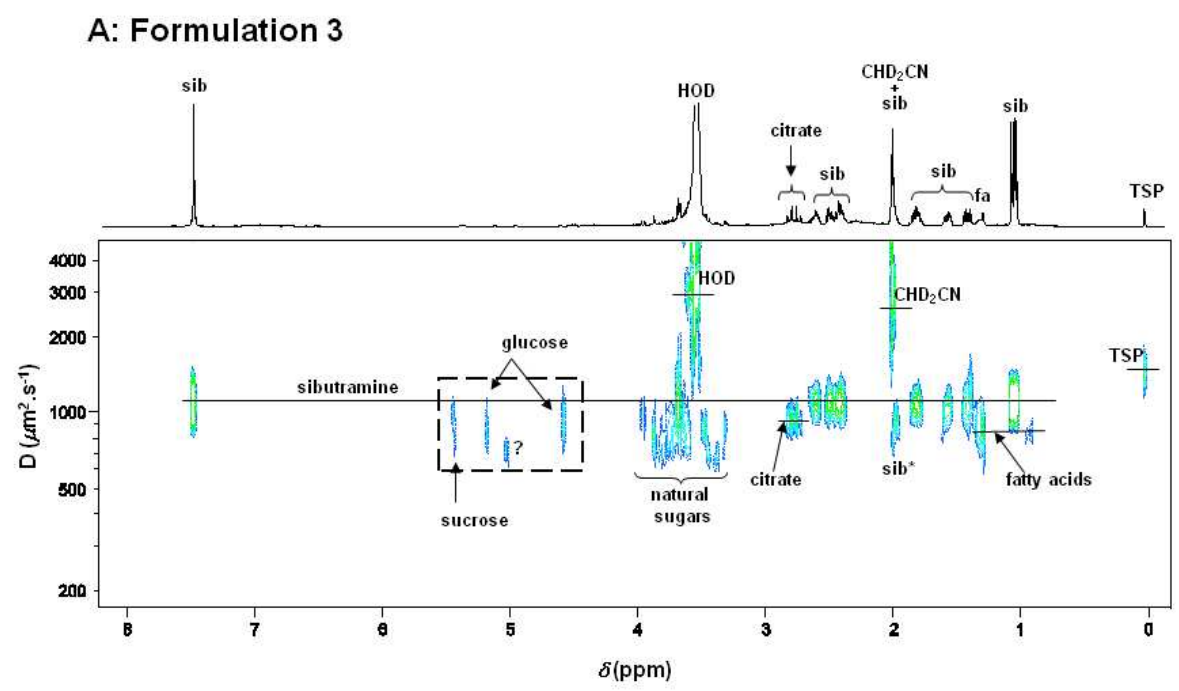

$254 \times 190 \mathrm{~mm}(96 \times 96 \mathrm{DPI})$ 
B: Formulation 12

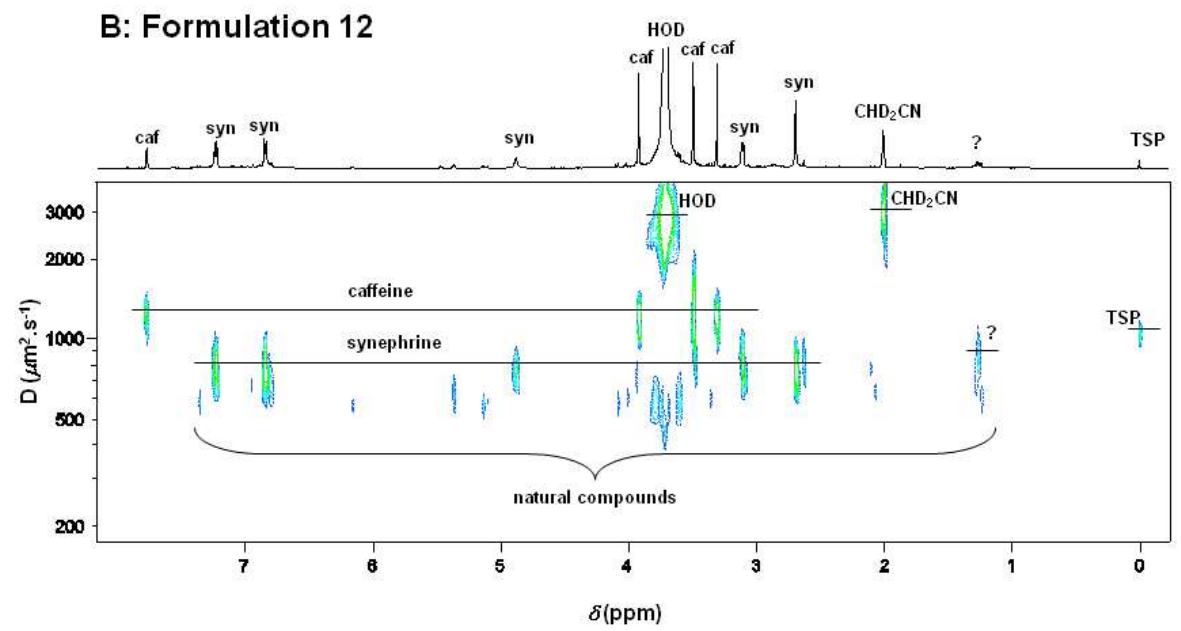


1

2

3

4

5

6

7

8

9

10

11

12

13

14

15

16

17

18

19

20

21

22

23

24

25

26

27

28

29

30

31

32

33

34

35

36

37

38

39

40

41

42

43

44

45

46

47

48

49

50

51

52

53

54

55

56

57

58

59

60

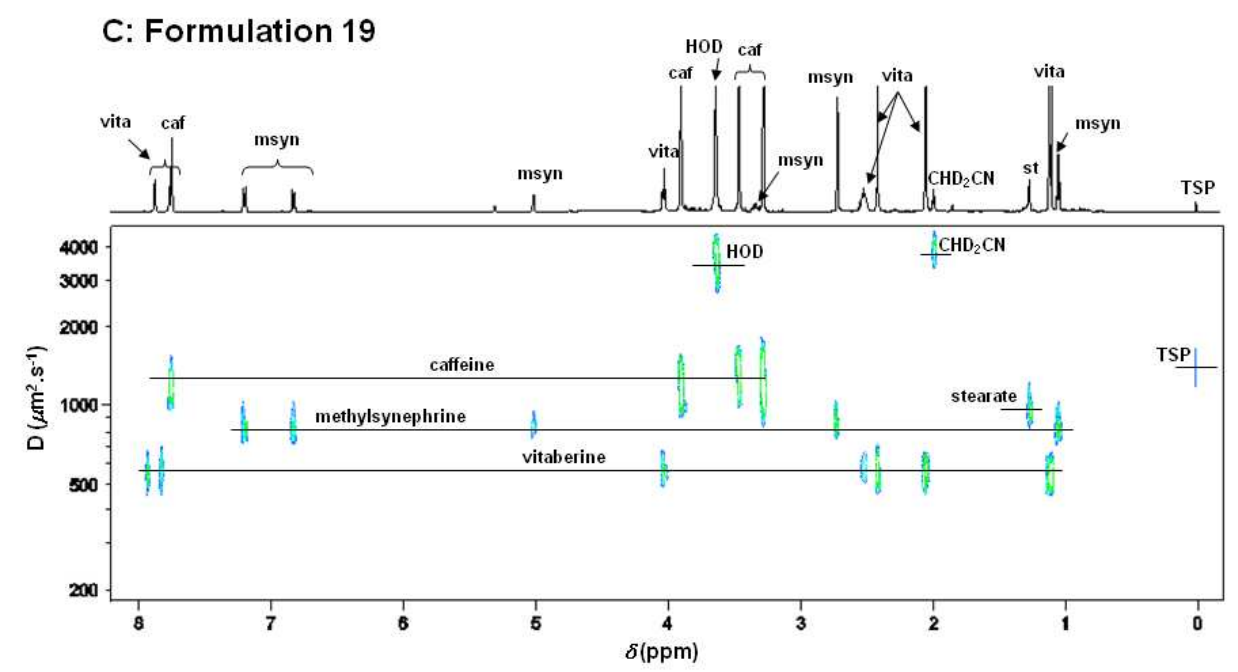

$254 \times 190 \mathrm{~mm}(96 \times 96 \mathrm{DPI})$ 



$254 \times 190 \mathrm{~mm}(96 \times 96 \mathrm{DPI})$

http://mc.manuscriptcentral.com/tfac Email: fac@tandf.co.uk 


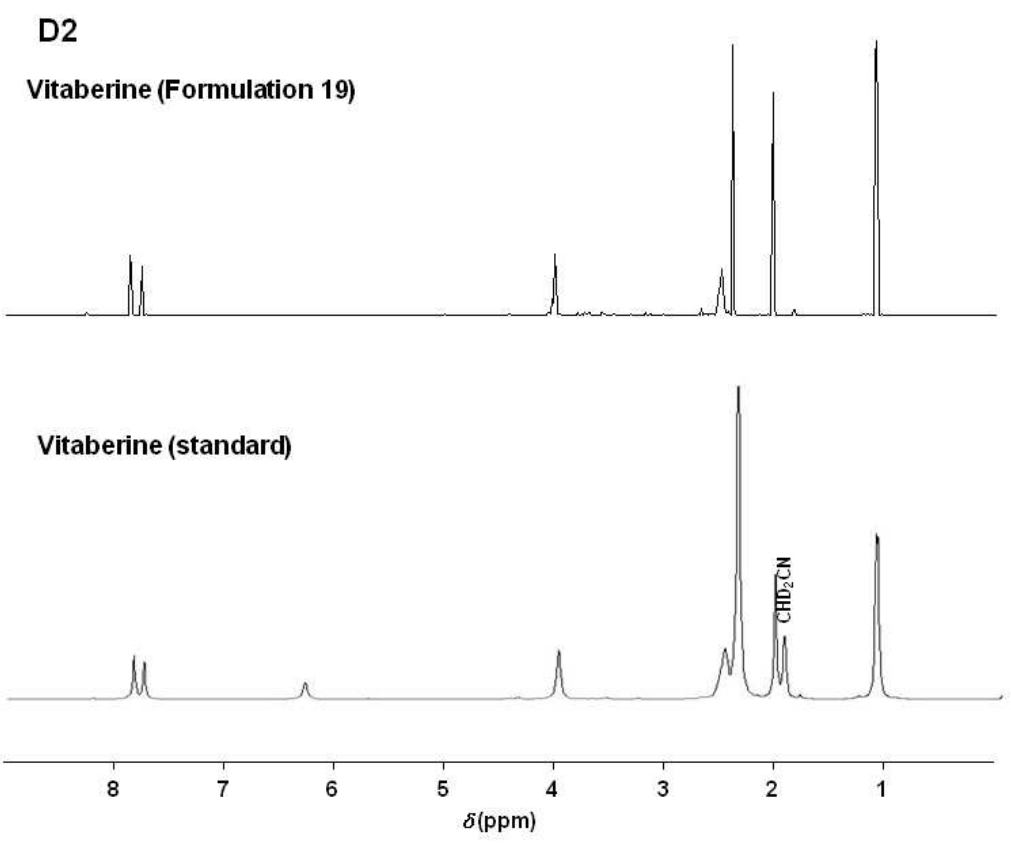

$254 \times 190 \mathrm{~mm}(96 \times 96 \mathrm{DPI})$ 

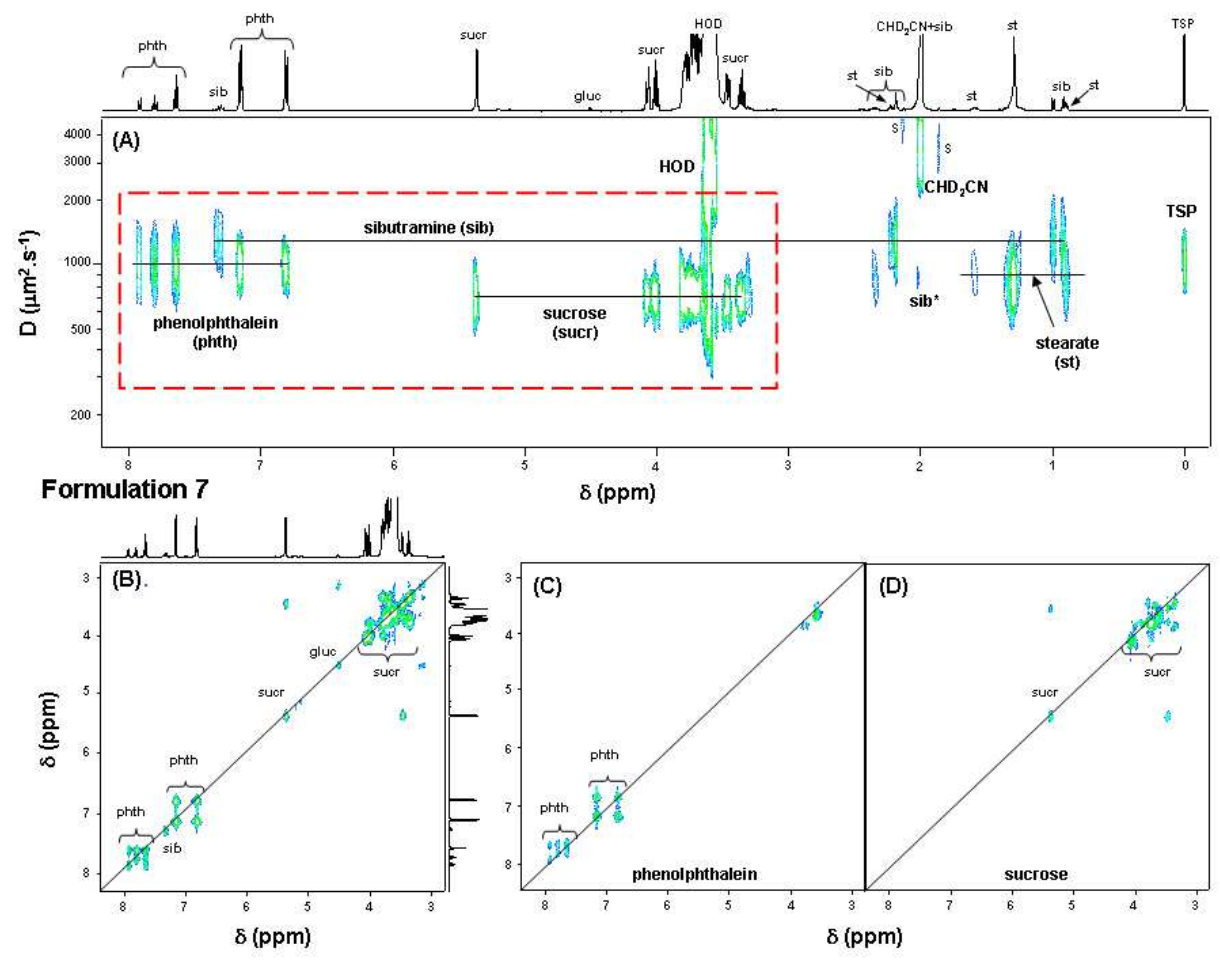

Fig 2

$254 \times 190 \mathrm{~mm}(96 \times 96$ DPI $)$

34

35

36

37

38

39

40

41

42

43

44

45

46

47

48

49

50

51

52

53

54

55

56

57

58

59

60

http://mc.manuscriptcentral.com/tfac Email: fac@tandf.co.uk 
Table 1. Herbal commercial formulations analyzed in this study.

\begin{tabular}{|c|c|c|c|c|c|c|c|}
\hline & $\begin{array}{c}\text { Formulation } \\
\text { name }\end{array}$ & Batch number & $\begin{array}{c}\text { Expiration } \\
\text { date }\end{array}$ & Manufacturer name & $\begin{array}{c}\text { Country of } \\
\text { manufacturing }\end{array}$ & $\begin{array}{l}\text { Product } \\
\text { form }\end{array}$ & Color \\
\hline 1 & $\begin{array}{c}\text { Perfect slim } \\
\text { cherry }\end{array}$ & 2007070183 & $07 / 2009$ & Chun Tian & Japan & Capsule & Pink \\
\hline 2 & 9 rapide 9 & $\begin{array}{c}\text { Q/CL5- } \\
\text { 2004n0487 }\end{array}$ & $05 / 2009$ & Zhengda health food & China & Capsule & Red \\
\hline 3 & Unknown $^{\mathrm{a}}$ & Unknown & Unknown & Unknown & China & Capsule & Red and white \\
\hline 4 & Unknown $^{\mathrm{a}}$ & Unknown & Unknown & Menova & China & Capsule & Blue \\
\hline 5 & $\begin{array}{l}\text { Perfect slim } \\
\text { grape }\end{array}$ & 2007080601 & $08 / 2009$ & Chun Tian & Japan & Capsule & $\begin{array}{l}\text { Green and } \\
\text { white }\end{array}$ \\
\hline 6 & Honey life & 20080302 & 03/2010 & $\mathrm{B} \& \mathrm{H}$ (USA) & China & Capsule & $\begin{array}{l}\text { Mauve and } \\
\text { white }\end{array}$ \\
\hline 7 & $\begin{array}{l}\text { Cider vinegar } \\
\text { dieting }\end{array}$ & 20080216 & $02 / 2010$ & Qinghai Oifield & China & Tablet & $\begin{array}{l}\text { Yellow (with } \\
\text { green spots) }\end{array}$ \\
\hline 8 & $\begin{array}{c}\text { Botanical } \\
\text { slimming soft } \\
\text { gel }\end{array}$ & 20081006 & $10 / 2010$ & Meizitang & China & $\begin{array}{l}\text { Capsule } \\
\text { with gel }\end{array}$ & Green \\
\hline 9 & $\begin{array}{c}\text { Botanical } \\
\text { slimming } \\
\text { Herbs }\end{array}$ & 0991-8280809 & 08/2010 & Meizitang & China & Capsule & $\begin{array}{l}\text { Orange and } \\
\text { brown }\end{array}$ \\
\hline 10 & $\begin{array}{l}2 \text { Day Diet } \\
\text { Japan Lingzhi } \\
\text { slimming } \\
\text { formula }\end{array}$ & Unknown & $12 / 2012$ & Unknown & Japan & Capsule & Purple \\
\hline 11 & Lipro diet pills & 20081020 & $10 / 2010$ & $\begin{array}{l}\text { China Karyhen } \\
\text { International Co. }\end{array}$ & China & Capsule & Green \\
\hline
\end{tabular}




\begin{tabular}{|c|c|c|c|c|c|c|c|}
\hline 12 & Lida & 20080924 & $09 / 2010$ & $\begin{array}{c}\text { Kunming Dali Industry } \\
\text { and Trade Co. }\end{array}$ & China & Capsule & Green \\
\hline 13 & $\begin{array}{c}\text { Onting } \\
\text { quianweisu } \\
\text { slimming } \\
\text { herbs }^{\mathrm{a}}\end{array}$ & Unknown & $03 / 2010$ & Menova & China & Capsule & Blue \\
\hline 14 & Meekeyes $^{\mathrm{a}}$ & 95882108 & Unknown & Marlian & China & Capsule & $\begin{array}{c}\text { Green and } \\
\text { white }\end{array}$ \\
\hline 15 & Perfect slim ${ }^{\mathrm{a}}$ & Unknown & Unknown & Unknown & China & Capsule & Pink \\
\hline 16 & Garslim & 22 & $05 / 2011$ & Balsam & Syria & Tablet & Beige \\
\hline 17 & $\begin{array}{c}\text { Alattar } \\
\text { psyllium }\end{array}$ & 4 & 06/2009 & Alattar Medical Co. & Syria & Capsule & Green \\
\hline 18 & $\begin{array}{c}\text { Alattar } \\
\text { slimming } \\
\text { mixture }\end{array}$ & $255161 \mathrm{M} 2$ & 06/2009 & Alattar Medical Co. & Syria & Powder & - \\
\hline 19 & $\begin{array}{c}\text { Hyper drive } \\
3.0+ \\
\end{array}$ & 110802 & $10 / 2013$ & ALR industries & USA & Capsule & Red \\
\hline 20 & Elan-Sil & 9.026 .6 & $01 / 2001$ & Vitaline Ltd & UK & Capsule & White \\
\hline
\end{tabular}

${ }^{\mathrm{a}}$ This formulation has been seized by French Customs. 
Table 2. Comparison of formulation composition with indications provided by the manufacturer.

\begin{tabular}{|c|c|c|c|c|}
\hline & $\begin{array}{c}\text { Formulation } \\
\text { name }\end{array}$ & $\begin{array}{l}\text { Indications provided by the } \\
\text { manufacturer }\end{array}$ & Compounds found & \\
\hline 1 & $\begin{array}{l}\text { Perfect slim } \\
\text { cherry }\end{array}$ & Only natural compounds & $\begin{array}{c}\text { Sibutramine } \\
\text { Phenolphtaleine } \\
\text { Vitamin } C^{\mathrm{a}} \\
\text { Very low amounts of natural compounds } \\
\text { including glucose, fructose, fatty acids }\end{array}$ & Identical to formulation $\mathbf{1 5}$ \\
\hline 2 & 9 rapide 9 & Only natural compounds & $\begin{array}{c}\text { Sibutramine } \\
\text { Very low amounts of natural compounds } \\
\text { including fatty acids }\end{array}$ & \\
\hline 3 & Unknown & No indication ${ }^{b}$ & $\begin{array}{c}\text { Sibutramine citrate } \\
\text { Low amounts of natural compounds } \\
\text { including glucose, fructose, fatty acids }\end{array}$ & \\
\hline 4 & Unknown & No indication ${ }^{\mathrm{b}}$ & $\begin{array}{c}\text { Sibutramine } \\
\text { Low amounts of natural compounds } \\
\text { including glucose, fructose, fatty acids }\end{array}$ & Identical to formulation $\mathbf{1 3}$ \\
\hline 5 & $\begin{array}{l}\text { Perfect slim } \\
\text { grape }\end{array}$ & Only natural compounds & $\begin{array}{c}\text { Sibutramine } \\
\text { Phenolphtaleine } \\
\text { Very low amounts of natural compounds } \\
\text { including glucose, fructose, fatty acids }\end{array}$ & $\begin{array}{l}\text { Very similar to formulation } 1 \text { except } \\
\text { that it contains no vitamin } \mathrm{C}\end{array}$ \\
\hline 6 & Honey life & $\begin{array}{l}\text { L-carnitine L-tartrate } \\
\text { Natural compounds (Konjac } \\
\text { flour, Cassia seed) }\end{array}$ & $\begin{array}{c}\text { Carnitine tartrate } \\
\text { Low amounts of natural compounds } \\
\text { including sugars, fatty acids and vitamin } \\
\text { B3 }\end{array}$ & \\
\hline 7 & $\begin{array}{l}\text { Cider vinegar } \\
\text { dieting }\end{array}$ & $\begin{array}{l}\text { Carnitine } \\
\text { Flavone glycoside } \\
\text { Oligosaccharide }\end{array}$ & $\begin{array}{c}\text { Sibutramine } \\
\text { Phenolphtaleine } \\
\text { Stearate } \\
\text { Sucrose } \\
\text { Very low amounts of natural sugars }\end{array}$ & No carnitine \\
\hline
\end{tabular}




\begin{tabular}{|c|c|c|c|c|}
\hline 8 & $\begin{array}{l}\text { Botanical } \\
\text { slimming soft } \\
\text { gel }\end{array}$ & Only natural compounds & $\begin{array}{l}\text { Sibutramine } \\
\text { Soybean oil }\end{array}$ & $\begin{array}{l}\text { Soybean oil is used to prepare the } \\
\text { gel }\end{array}$ \\
\hline 9 & $\begin{array}{c}\text { Botanical } \\
\text { slimming herbs }\end{array}$ & Only natural compounds & $\begin{array}{c}\text { Sibutramine } \\
\text { Phenolphtaleine } \\
\text { Very low amounts of natural compounds } \\
\text { including glucose, sucrose, fatty acids }\end{array}$ & \\
\hline 10 & $\begin{array}{l}2 \text { Day Diet } \\
\text { Japan Lingzhi } \\
\text { slimming } \\
\text { formula }\end{array}$ & Only natural compounds & $\begin{array}{l}\text { Sibutramine } \\
\text { Very low amounts of natural compounds } \\
\text { including glucose, fatty acids }\end{array}$ & \\
\hline 11 & Lipro diet pills & $\begin{array}{l}\text { Only natural compounds } \\
\text { (Chinese herbs) }\end{array}$ & $\begin{array}{c}\text { Sibutramine } \\
\text { Stearate } \\
\text { Very low amounts of natural sugars } \\
\text { including glucose } \\
\end{array}$ & \\
\hline 12 & Lida & $\begin{array}{l}\text { Only natural compounds } \\
\text { (Yunnan herbs) }\end{array}$ & $\begin{array}{c}\text { Caffeine } \\
\text { Synephrine } \\
\text { Low amount of natural compounds } \\
\end{array}$ & \\
\hline 13 & $\begin{array}{c}\text { Onting } \\
\text { quianweisu } \\
\text { slimming herbs }\end{array}$ & No indication ${ }^{b}$ & $\begin{array}{c}\text { Sibutramine } \\
\text { Low amounts of natural compounds } \\
\text { including glucose, fructose, fatty acids }\end{array}$ & Identical to formulation 4 \\
\hline 14 & Meekeyes & No indication ${ }^{\mathrm{b}}$ & $\begin{array}{c}\text { Sibutramine } \\
\text { Sucrose } \\
\text { Fatty acid } \\
\text { High amount of sinapine and very } \\
\text { low amounts of other natural compounds }\end{array}$ & \\
\hline 15 & Perfect slim & No indication ${ }^{\mathrm{b}}$ & $\begin{array}{c}\text { Sibutramine } \\
\text { Phenolphtaleine } \\
\text { Vitamin } C^{\mathrm{a}} \\
\text { Very low amounts of natural compounds } \\
\text { including glucose, fructose, fatty acids }\end{array}$ & Identical to formulation $\mathbf{1}$ \\
\hline 16 & Garslim & $\begin{array}{c}\text { Fruit extracts with } 50 \% \\
\text { hydroxycitric acid and citric acid }\end{array}$ & $\begin{array}{l}\text { Hydroxycitric acid } \\
\text { Citric acid }\end{array}$ & \\
\hline
\end{tabular}




\begin{tabular}{|c|c|c|c|c|}
\hline 17 & $\begin{array}{l}\text { Alattar } \\
\text { psyllium }\end{array}$ & $\begin{array}{l}\text { Mucilages, fatty oil, iridoide } \\
\text { monoterpenes }\end{array}$ & $\begin{array}{l}\text { Fatty acids including stearic and linoleic } \\
\text { acids }\end{array}$ & \\
\hline 18 & $\begin{array}{l}\text { Alattar } \\
\text { slimming } \\
\text { mixture }\end{array}$ & Only natural compounds & $\begin{array}{l}\text { Only natural compounds including } \\
\text { caffeine, polyphenols, sugars, fatty acids }\end{array}$ & \\
\hline 19 & $\begin{array}{l}\text { Hyper drive } \\
3.0\end{array}$ & $\begin{array}{c}\text { Methylsynephrine } \\
\text { Xanthines } \\
\text { Vitaberine } \\
\text { Lipoic acid } \\
\text { Tyrosine ethyl ester } \\
\text { Propionylcarnitine ethyl ester } \\
\text { Natural compounds } \\
\end{array}$ & $\begin{array}{c}\text { Methylsynephrine } \\
\text { Caffeine } \\
\text { Vitaberine } \\
\text { Stearate } \\
\text { Very low amounts of natural compounds }\end{array}$ & $\begin{array}{c}\text { The amounts of lipoic acid and } \\
\text { tyrosine ethyl ester are probably too } \\
\text { low to be detected. Both compounds } \\
\text { were undetected with }{ }^{1} \mathrm{H} \text { NMR or } \\
\text { MS. }\end{array}$ \\
\hline 20 & Elan-Sil & $\begin{array}{c}\text { L-carnitine L-tartrate } \\
\text { Vitamin C } \\
\text { Vitamin E acetate } \\
\text { Vitamin B1 } \\
\text { Vitamin B2 } \\
\text { Vitamin B3 } \\
\text { Vitamin B5 (Ca pantothenate) } \\
\text { Vitamin B6 } \\
\text { Vitamin B7 } \\
\text { Vitamin B9 } \\
\text { Vitamin B12 } \\
\text { Mg salts of fatty acids }\end{array}$ & $\begin{array}{c}\text { Carnitine } \\
\text { Vitamin C }^{\mathrm{a}} \\
\text { Vitamin E acetate } \\
\text { Vitamin B1 } \\
\text { Vitamin B3 } \\
\text { Vitamin B5 } \\
\text { Vitamin B6 } \\
\text { Stearate }\end{array}$ & $\begin{array}{l}\text { Tartrate was not detected. } \\
\text { The amounts of vitamins B2, B7, B9 } \\
\text { and B12 are too low to be detected. }\end{array}$ \\
\hline
\end{tabular}


Table 3. NMR characteristics of sibood Additives and Contaminants

\begin{tabular}{|c|c|c|c|}
\hline & Sibutram & 17 & \\
\hline $\begin{array}{c}\text { Atom } \\
\text { number }\end{array}$ & $\delta{ }^{1} \mathrm{H}(\mathrm{ppm})^{\mathrm{a}}$ & $\begin{array}{l}\text { Multiplicity }^{\mathrm{b}} \\
(\mathrm{J} \text { in } \mathrm{Hz})\end{array}$ & $\delta^{13} \mathrm{C}(\mathrm{ppm})$ \\
\hline 1 & 28 & & 49.2 \\
\hline 2 or 4 & $\begin{array}{l}2.60 \text { (1H syn aromatic ring) } \\
2.49 \text { (1H anti aromatic ring) }\end{array}$ & $\begin{array}{l}\mathrm{m} \\
\mathrm{m}\end{array}$ & 32.5 \\
\hline 3 & $\begin{array}{l}1.98(1 \mathrm{H}) \\
1.78(1 \mathrm{H})\end{array}$ & $\begin{array}{l}\mathrm{m} \\
\mathrm{m}\end{array}$ & 15.5 \\
\hline 4 or 2 & $\begin{array}{l}2.37 \text { (1H syn aromatic ring) } \\
2.41 \text { (1H anti aromatic ring) }\end{array}$ & $\begin{array}{l}\mathrm{m} \\
\mathrm{m}\end{array}$ & 33.7 \\
\hline 5 & $-\gamma$ & - & 140.2 \\
\hline 6,10 & 747 & & 128.7 \\
\hline 7,9 & 1.47 & $\mathrm{~S}$ & 129.9 \\
\hline 8 & $P$ & & 132.9 \\
\hline 11 & 3.67 & $\mathrm{t}(6.3)$ & 71.7 \\
\hline 12 or 13 & 2.19 & broad $\mathrm{s}$ & $39.6^{\mathrm{c}}$ \\
\hline 13 or 12 & 2.81 & broad s & $47.0^{c}$ \\
\hline 14 & $\begin{array}{l}1.53(1 \mathrm{H}) \\
1.39(1 \mathrm{H})\end{array}$ & $\begin{array}{l}\mathrm{m} \\
\mathrm{m}\end{array}$ & 33.5 \\
\hline 15 & 1.78 & $\mathrm{~m}$ & 25.4 \\
\hline 16 or 17 & 1.01 & $\mathrm{~d}(6.5)$ & 22.0 \\
\hline 17 or 16 & 1.04 & $\mathrm{~d}(6.5)$ & 21.2 \\
\hline
\end{tabular}

${ }^{a}$ The value given is the chemical shift of the centre of the signal.

${ }^{\mathrm{b}} \mathrm{s}$ : singlet; d: doublet; t: triplet; m: multiplet.

${ }^{c}$ The chemical shift of this carbon was measured in a spectrum recorded in $\mathrm{CD}_{3} \mathrm{CN}$. 
Table 4. ${ }^{1} \mathrm{H}$ NMR characteristics of the main signals of ingredients found in herbal formulations (except sibutramine given in Table 3).

\begin{tabular}{|c|c|}
\hline Compound & ${ }^{1} \mathrm{H}$ NMR $\delta(\mathrm{ppm})^{\mathrm{a}}$ and multiplicity ${ }^{\mathrm{b}}(\mathrm{J}, \mathrm{Hz})$ \\
\hline phenolphthalein & $\begin{array}{c}7.93 \mathrm{~d}(7.5 ; \mathrm{H} 8), 7.79 \mathrm{t}(7.5 ; \mathrm{H} 6), 7.63 \mathrm{t}(7.0 ; \mathrm{H} 7), 7.63 \mathrm{~d}(7.5 ; \mathrm{H} 6), \\
7.17 \mathrm{~d}(8.5 ; 4 \mathrm{H} 11), 6.84 \mathrm{~d}(8.5 ; 4 \mathrm{H} 12)\end{array}$ \\
\hline synephrine & $\begin{array}{c}7.23 \mathrm{~d}(8.5 ; \mathrm{Ar}), 6.83 \mathrm{~d}(8.5 ; \mathrm{Ar}), 4.70 \mathrm{dd}(4.3,8.8 ; \mathrm{CHOH}), 2.70 \\
\text { ABd system }\left(12.3,8.8,4.3 ; \mathrm{CH}_{2}\right), 2.36 \mathrm{~s}\left(\mathrm{CH}_{3}\right)\end{array}$ \\
\hline methylsynephrine ${ }^{c}$ & $\begin{array}{c}7.20 \mathrm{~d}(8.5 ; \mathrm{Ar}), 6.83 \mathrm{~d}(8.5 ; \mathrm{Ar}), 5.00 \mathrm{~d}(3.1 ; \mathrm{CHOH}), 3.34 \mathrm{qd}(3.1, \\
\text { 6.7; } \underline{\mathrm{H}} \underline{\mathrm{H} H}), 2.71 \mathrm{~s}\left(\mathrm{C}_{3}{ }_{3} \mathrm{NH}\right), 1.04 \mathrm{~d}\left(6.7 ; \underline{\mathrm{CH}}_{3} \mathrm{CH}\right)\end{array}$ \\
\hline $\begin{array}{l}\text { vitaberine } \\
\text { (sulbutiamine) }\end{array}$ & $\begin{array}{c}7.86 \mathrm{~s}(\mathrm{H} \text { pyrim }), 7.77 \mathrm{~s}(\mathrm{CHO}), 4.45 \text { centre of a very broad s } \\
\left(\mathrm{CH}_{2} \mathrm{~N}\right), 4.04 \mathrm{t}\left(6.3 ; \mathrm{CH}_{2} \mathrm{O}\right), 2.55 \mathrm{sept}\left(7.0 ; \mathrm{CH}\left(\mathrm{CH}_{3}\right)_{2}\right), 2.52 \text { broad t } \\
\left(6.3 ; \underline{\mathrm{CH}}_{2} \mathrm{CH}_{2} \mathrm{O}\right), 2.39 \mathrm{~s}\left(\mathrm{CH}_{3} \text { pyrim }\right), 2.05 \mathrm{~s}\left(\mathrm{CH}_{3} \mathrm{C}=\mathrm{C}-\right), 1.12 \mathrm{~d}(7.0 ; \\
\left.\mathrm{CH}\left(\mathrm{C}_{3}\right)_{2}\right)\end{array}$ \\
\hline riboflavine & $\begin{array}{c}8.00 \mathrm{~s}(\mathrm{Ar}), 7.99 \mathrm{~s}(\mathrm{Ar}), 4.93 \mathrm{~m}\left(\mathrm{CH}_{2} \mathrm{~N}\right), 4.37 \mathrm{~m}(\underline{\mathrm{CHOH}}), 3.87 \mathrm{~m} \\
(\underline{\mathrm{CHOH}}), 3.79 \mathrm{~m}(\underline{\mathrm{CH}} \underline{\mathrm{OH}}), 3.66 \mathrm{~m}(\underline{\mathrm{CHOH}}), 2.58 \mathrm{~s}\left(\mathrm{CH}_{3}-\mathrm{Ar}\right), 2.48 \mathrm{~s} \\
\left(\mathrm{CH}_{3}-\underline{\mathrm{Ar}}\right)\end{array}$ \\
\hline caffeine & $7.77 \mathrm{~s}(\mathrm{H}), 3.93 \mathrm{~s}\left(\mathrm{CH}_{3}\right), 3.50 \mathrm{~s}\left(\mathrm{CH}_{3}\right), 3.32 \mathrm{~s}\left(\mathrm{CH}_{3}\right)$ \\
\hline carnitine & $\begin{array}{c}4.56 \text { app q }(7.0 ; \mathrm{C} \underline{\mathrm{HOH}}), 3.45-3.31 \mathrm{~m}\left(\mathrm{CH}_{2} \mathrm{~N}^{+}\right), 3.19 \mathrm{~s}\left(\left(\mathrm{CH}_{3}\right)_{3} \mathrm{~N}^{+}\right), \\
2.62-2.53 \mathrm{~m}\left(\mathrm{CH}_{2} \mathrm{COOH}\right)\end{array}$ \\
\hline lipoic acid & $\begin{array}{c}3.62 \mathrm{~m}(\mathrm{H} 3), 3.20 \mathrm{~m}(\mathrm{H} 5 \alpha), 3.13 \mathrm{~m}(\mathrm{H} 5 \beta), 2.46 \operatorname{sext}(6.2 ; \mathrm{H} 4 \alpha), 2.30 \\
\mathrm{t}(7.4 ; \mathrm{H} 9), 1.91 \operatorname{sext}(6.7 ; \mathrm{H} 4 \beta), 1.72 \mathrm{~m}(\mathrm{H} 6 \alpha), 1.61 \mathrm{~m}(\mathrm{H} 6 \beta, \mathrm{H} 8) \\
1.44 \mathrm{~m}(\mathrm{H} 7)\end{array}$ \\
\hline stearate & $\begin{array}{c}2.21 \mathrm{t}\left(7.5 ; \mathrm{CH}_{2} \mathrm{CO}\right), 1.53 \text { quin }\left(6.9 ; \mathrm{C}_{2} \underline{\mathrm{CH}}_{2} \mathrm{CO}\right), 1.27 \text { broad s }(14 \\
\left.\mathrm{CH}_{2}\right), 0.98 \mathrm{t}\left(6.9 ; \mathrm{CH}_{3}\right)\end{array}$ \\
\hline linoleic acid & $\begin{array}{c}5.36 \mathrm{~m}(4=\mathrm{CH}), 2.78 \mathrm{t}\left(6.6 ;=\mathrm{CH}-\mathrm{CH}_{2}-\mathrm{CH}=\right), 2.26 \mathrm{t}\left(7.5 ;-\underline{\mathrm{CH}}_{2^{-}}\right. \\
\mathrm{COOH}), 2.06 \mathrm{q}\left(6.8 ; 2-\mathrm{CH}_{2}-\mathrm{CH}_{2}-\mathrm{CH}=\right), 1.55 \text { quin }\left(6.9 ;-\underline{\mathrm{CH}}_{2}-\mathrm{CH}_{2^{-}}\right. \\
\mathrm{COOH}), 1.32 \mathrm{~m}\left(7 \mathrm{CH}_{2}\right), 0.89 \mathrm{t}\left(6.9 ; \mathrm{CH}_{3}\right)\end{array}$ \\
\hline sinapine $^{\mathrm{d}}$ & $\begin{array}{l}7.65 \mathrm{~d}(15.9 ; \mathrm{Ar}-\mathrm{CH}=), 6.96 \mathrm{~s}(\mathrm{Ar}), 6.48 \mathrm{~d}(15.9 ;=\mathrm{CH}-\mathrm{COO}-), 4.57 \mathrm{~m} \\
\left(\mathrm{O}-\mathrm{CH}_{2}\right), 3.87 \mathrm{~s}\left(\mathrm{OCH}_{3}\right), 3.68 \mathrm{~m}\left(-\mathrm{C}_{\underline{H}}-{ }^{-}\left(\mathrm{CH}_{3}\right)_{3}{ }^{+}\right), 3.17 \mathrm{~s}\left(\mathrm{~N}^{-}\left(\mathrm{CH}_{3}\right)_{3}{ }^{+}\right) \\
\end{array}$ \\
\hline citrate & 2.75 AB system $\left(17.3 ; \mathrm{CH}_{2}\right)$ \\
\hline vitamin $\mathrm{C}$ & $\begin{array}{c}4.78 \mathrm{~d}(2.0 ; \mathrm{CH}-\mathrm{O}-), 3.89 \text { td }(\mathrm{X} \text { part of the } \mathrm{ABX} \text { system })(2.0,6.7 ; \\
\mathrm{C} \underline{\mathrm{HOH}}), \mathrm{AB} \text { part of the } \mathrm{ABX} \text { system: } \delta_{\mathrm{A}}=3.62, \delta_{\mathrm{B}}=3.60\left(\mathrm{~J}_{\mathrm{AB}}=11.2,\right. \\
\left.\mathrm{J}_{\mathrm{AX}}=\mathrm{J}_{\mathrm{BX}}=6.7 ; \underline{\mathrm{C}}_{2} \mathrm{OH}\right)\end{array}$ \\
\hline dehydroascorbic acid & $\begin{array}{c}4.58 \mathrm{~s}(\mathrm{CHO}), 4.43 \mathrm{dd}(5.6,3.1 ; \mathrm{CHOH}), 4.21 \mathrm{dd}(5.6,10.2 ; 1 \mathrm{H} \text { of } \\
\left.\mathrm{CH}_{2} \mathrm{OH}\right), 4.05 \mathrm{dd}\left(3.1,10.2 ; 1 \mathrm{H} \text { of } \mathrm{CH}_{2} \mathrm{OH}\right)\end{array}$ \\
\hline $\begin{array}{l}\text { vitamin B1 } \\
\text { (thiamine) }\end{array}$ & $\begin{array}{c}\text { 9.56 s ( } \mathrm{H} \text { thiazole ring), } 7.97 \mathrm{~s}(\mathrm{H} \text { pyrimidine ring }), 5.47 \mathrm{~s}\left(\mathrm{CH}_{2} \mathrm{~N}^{+}\right) \\
3.82 \mathrm{t}\left(5.6 ; \underline{\mathrm{C}}_{2} \mathrm{OH}\right), 3.13 \mathrm{t}\left(5.6 ; \mathrm{C}_{2}{ }_{2} \mathrm{CH}_{2} \mathrm{OH}\right), 2.61 \mathrm{~s}\left(\mathrm{CH}_{3}\right), 2.50 \mathrm{~s} \\
\left(\mathrm{CH}_{3}\right)\end{array}$ \\
\hline $\begin{array}{l}\text { vitamin B3 } \\
\text { (niacin) }\end{array}$ & $\begin{array}{c}8.98 \mathrm{~d}(2.1 ; \mathrm{H} 2), 8.70 \mathrm{dd}(4.9,1.7 ; \mathrm{H} 6), 8.23 \mathrm{td}(8.0,1.7 ; \mathrm{H} 4), 7.52 \mathrm{dd} \\
(4.9,8.0 ; \mathrm{H} 5)\end{array}$ \\
\hline $\begin{array}{c}\text { vitamin B5 } \\
\text { (pantothenic acid) }\end{array}$ & $\begin{array}{c}3.90 \mathrm{~s}(\mathrm{C} \underline{\mathrm{HOH}}), 3.46-3.34 \mathrm{~m}\left(\mathrm{CH}_{2} \mathrm{OH} \text { and } \mathrm{CH}_{2} \mathrm{NHCO}\right), 2.33 \mathrm{t}(6.7 ; \\
\left.\mathrm{C}_{\underline{H}} \mathrm{COOH}\right), 0.89 \mathrm{~s}\left(\mathrm{CH}_{3}\right), 0.88 \mathrm{~s}\left(\mathrm{CH}_{3}\right)\end{array}$ \\
\hline $\begin{array}{l}\text { vitamin B6 } \\
\text { (pyridoxine) }\end{array}$ & $8.08 \mathrm{~s}(\mathrm{H}), 5.04 \mathrm{~s}\left(\mathrm{C}_{2} \underline{\mathrm{OH}}_{2}\right), 4.67 \mathrm{~s}\left(\mathrm{C}_{2} \underline{\mathrm{OH}}_{2}\right), 2.59 \mathrm{~s}\left(\mathrm{CH}_{3}\right)$ \\
\hline $\begin{array}{c}\text { vitamin } \mathrm{E} \\
\text { (tocopherol acetate) }\end{array}$ & $\begin{array}{l}2.62 \mathrm{t}\left(6.8 ;=\mathrm{C}_{-} \mathrm{CH}_{2}-\right), 2.31 \mathrm{~s}\left(\mathrm{CH}_{3}-\mathrm{COO}^{-}\right), 2.08 \mathrm{~s}\left(\mathrm{CH}_{3}-\mathrm{Ar}\right), 1.99 \mathrm{~s} \\
\left(\mathrm{CH}_{3}-\mathrm{Ar}\right), 1.96 \mathrm{~s}\left(\mathrm{CH}_{3}-\mathrm{Ar}\right), 1.82 \mathrm{~m}\left(\mathrm{O}-\mathrm{C}-\mathrm{CH}_{2}\right), 1.53 \mathrm{~m}\left(\underline{\mathrm{HC}}-\mathrm{CH}_{3}\right), \\
1.41 \mathrm{~m}\left(\underline{\mathrm{HC}}-\mathrm{CH}_{3}\right), 1.27 \mathrm{~m}\left(\mathrm{CH}_{2}\right), 1.25 \mathrm{~s}\left(\mathrm{CH}_{3}-\mathrm{C}-\mathrm{O}\right), 1.16 \mathrm{~m}\left(\mathrm{CH}_{2}\right), \\
\quad 1.09 \mathrm{~m}\left(\mathrm{CH}_{2}\right), 0.88 \mathrm{~d}\left(6.6 ; \mathrm{HC}-(\underline{\mathrm{CH}} 3), 0.86 \mathrm{~d}\left(6.6 ; \mathrm{HC}-\mathrm{CH}_{3}\right)\right.\end{array}$ \\
\hline
\end{tabular}




\begin{tabular}{c|c}
\hline \hline$\alpha / \beta$-glucose & $5.14 \mathrm{~d}(3.5 ; \mathrm{H} 1 \alpha), 4.53 \mathrm{~d}(8.0 ; \mathrm{H} 1 \beta), 3.84-3.71 \mathrm{~m}, 3.71-3.60 \mathrm{~m}, 3.45-$ \\
& $3.28 \mathrm{~m}, 3.15 \mathrm{t}(8.0 ; \mathrm{H} 2 \beta)$ \\
\hline fructose & $4.06-3.99 \mathrm{~m}, 3.99-3.85 \mathrm{~m}, 3.85-3.68 \mathrm{~m}, 3.67-3.42 \mathrm{~m}$ \\
\hline \multirow{2}{*}{ sucrose $^{\mathrm{e}}$} & $\begin{array}{c}5.36 \mathrm{~d}(3.5 ; \mathrm{g} 1), 4.10 \mathrm{~d}(8.5 ; \mathrm{f} 3), 4.00 \mathrm{t}(8.5 ; \mathrm{f} 4), 3.83-3.67 \mathrm{~m}(\mathrm{f} 5, \mathrm{~g} 5, \\
\text { f6, g6, g3), 3.61 AB system }(12.5 ; \mathrm{f} 1), 3.48 \mathrm{dd}(3.5,10.0 ; \mathrm{g} 2), 3.38 \mathrm{t} \\
(9.5 ; \mathrm{g} 4)\end{array}$ \\
\hline \hline
\end{tabular}

\footnotetext{
${ }^{\mathbf{a}}$ Spectral data were measured from authentic standards in $\mathrm{CD}_{3} \mathrm{CN}: \mathrm{D}_{2} \mathrm{O}(80: 20)$.

b s: singlet; d: doublet; dd: doublet of doublet; t: triplet; td: doublet of triplet; q: quadruplet; quin: quintuplet; sext: sextuplet; sept: septuplet; m: multiplet; app: apparent.

${ }^{\mathbf{c}}$ The chemical shifts were measured in the spectrum of formulation 19.

${ }^{\mathbf{d}}$ The structure of sinapine (choline ester of sinapic acid) was determined with $1 \mathrm{D}$ and $2 \mathrm{D}{ }^{1} \mathrm{H}$ and ${ }^{13} \mathrm{C}$ NMR experiments on formulation 14 and confirmed by $\mathrm{MS}\left(\left[\mathrm{M}^{+}\right] 310\right)$.

${ }^{\mathbf{e}} \mathrm{g}$ : glucose; f: fructose.
} 
Table 5. Amounts of adulterant sibutramine and phenolphthalein found in claimed herbal medicines analyzed in this study.

\begin{tabular}{|c|c|c|}
\hline Formulation number & $\begin{array}{c}\text { Sibutramine } \\
\text { mg/capsule or tablet } \\
\text { mean } \pm \text { SD } \\
(\mathrm{n}=3)\end{array}$ & $\begin{array}{c}\text { Phenolphtalein } \\
\text { mg/capsule or tablet } \\
\text { mean } \pm \text { SD } \\
(\mathrm{n}=3)\end{array}$ \\
\hline 1 & $13.1 \pm 0.3$ & $47.0 \pm 3.0$ \\
\hline 2 & $4.4 \pm 0.3$ & - \\
\hline 3 & $23.3 \pm 0.1$ & - \\
\hline 4 & $15.6 \pm 0.5$ & - \\
\hline 5 & $19.6 \pm 0.5$ & $66.1 \pm 1.4$ \\
\hline 7 & $5.0 \pm 0.1$ & $36.2 \pm 0.5$ \\
\hline 8 & $12.7 \pm 0.2$ & - \\
\hline 9 & $12.0 \pm 0.2$ & $4.4 \pm 0.2$ \\
\hline 10 & $10.6 \pm 0.3$ & - \\
\hline 11 & $30.5 \pm 0.1$ & - \\
\hline 13 & $15.1 \pm 0.3$ & - \\
\hline 14 & $14.0 \pm 0.7$ & - \\
\hline 15 & $13.7 \pm 0.6$ & $40.8 \pm 1.3$ \\
\hline
\end{tabular}


Table 6. Adulterants found in herbal products or dietary supplements marketed as slimming products reported in literature

\begin{tabular}{|c|c|c|c|c|}
\hline References & $\begin{array}{l}\text { Analytical } \\
\text { methods for } \\
\text { detection }\end{array}$ & $\begin{array}{c}\text { Number of } \\
\text { formulations } \\
\text { analysed } \\
\end{array}$ & $\begin{array}{l}\text { Active Pharmaceutical } \\
\text { Ingredients detected }\end{array}$ & $\begin{array}{c}\text { Other compounds } \\
\text { detected }\end{array}$ \\
\hline Tseng et al. 2000 & GC-MS & 4 & $\begin{array}{c}\text { Mazindol } \\
\text { Clobenzorex } \\
\text { Diazepam } \\
\text { Phentermine } \\
\text { Caffeine } \\
\end{array}$ & \\
\hline Jung et al. 2006 & $\begin{array}{c}\text { GC-MS } \\
\text { HPLC-DAD }\end{array}$ & 1 & Sibutramine & \\
\hline Blachut et al. 2007 & GC-MS & 1 (Lida) & N-desmethylsibutramine & \\
\hline $\begin{array}{c}\text { Sein Anand and } \\
\text { Chodorowski } \\
2007 \\
\end{array}$ & GC-MS & 1 (Meizitanc) & Sibutramine & \\
\hline Bogusz et al. 2006 & LC-ESI-MS/MS & 1 & $\begin{array}{c}\text { Fenfluramine } \\
\text { Phentermine } \\
\text { Caffeine } \\
\end{array}$ & \\
\hline Zou et al. 2007 & $\begin{array}{l}\text { LC-MS/MS } \\
\text { LC-TOF-MS }\end{array}$ & 1 & $\begin{array}{c}\text { Sibutramine } \\
\text { N-desmethylsibutramine } \\
\text { N-didesmethylsibutramine } \\
\text { Homosibutramine }\end{array}$ & \\
\hline Date et al. 2008 & LC-ESI-MS/MS & 10 & $\begin{array}{c}\text { Phenolphthalein } \\
\text { Sibutramine } \\
\text { Mazindol } \\
\text { Sennosides A and B } \\
\text { Bisacodyl } \\
\text { Hydrochlorothiazide }\end{array}$ & \\
\hline Huang et al. 2008 & LC-ESI-MS & 15 & $\begin{array}{c}\text { Sibutramine } \\
\text { N-didesmethylsibutramine }\end{array}$ & \\
\hline Wang et al. 2008 & LC-ESI-MS & 6 & $\begin{array}{c}\text { Sibutramine } \\
\text { Phenolphthalein } \\
\text { N-desmethylsibutramine }\end{array}$ & \\
\hline Chen et al. 2009 & $\begin{array}{l}\text { QTRAP LC- } \\
\text { MS/MS }\end{array}$ & 18 & $\begin{array}{c}\text { Fenfluramine } \\
\text { Sibutramine } \\
\text { Phenolphthalein } \\
\end{array}$ & \\
\hline $\begin{array}{l}\text { Cianchino et al. } \\
2008\end{array}$ & $\mathrm{CE}$ & 4 & $\begin{array}{c}\text { Ephedrine } \\
\text { Norephedrine } \\
\text { Furosemide } \\
\text { Caffeine }\end{array}$ & \\
\hline This study & $\begin{array}{l}{ }^{1} \mathrm{H} \text { NMR and } \\
2 \mathrm{D} \mathrm{DOSY}{ }^{1} \mathrm{H} \\
\text { NMR }\end{array}$ & 20 & $\begin{array}{c}\text { Sibutramine } \\
\text { Phenophthalein } \\
\text { Synephrine } \\
\text { Methylsynephrine } \\
\text { Vitaberin } \\
\text { Caffeine }\end{array}$ & $\begin{array}{c}\text { Carnitine } \\
\text { Vitamin C } \\
\text { Dehydroascorbic acid } \\
\text { Vitamins B1, B3, B5, } \\
\text { B6, E } \\
\text { Glucose } \\
\text { Fructose } \\
\text { Sucrose } \\
\text { Stearate } \\
\text { Linoleate } \\
\text { Citrate } \\
\text { Hydroxycitrate } \\
\text { Tartrate } \\
\text { Sinapine }\end{array}$ \\
\hline
\end{tabular}

